\title{
DERMATOGLYPHICS IN CARCINOMA BREAST
}

\author{
Savithri Krishnan ${ }^{1}$, Dimple Natesan ${ }^{2}$
}

1 Professor, Department of Anatomy, Government Medical College, Kollam.

${ }^{2}$ Senior Resident, Department of Anatomy, Government T. D. Medical College, Alappuzha.

ABSTRACT

\section{BACKGROUND}

Dermatoglyphics has been used to study the patterns of various diseases and is also used as a screening tool. Carcinoma breast is one of the common cancers affecting the females and since the development of milk ridges and mammary buds coincide with the development of dermal ridges in the volar pads, the pattern of dermal ridges may be linked with Carcinoma breast.

\section{MATERIALS AND METHODS}

The fingertip patterns and impressions of the palm were taken by the Roller \& Ink method in an executive bond paper. Digital patterns, pattern intensity, total finger ridge count (TFRC), absolute finger ridge count (AFRC), a-b ridge count, atd angle were studied and their significance analysed in 100 histopathologically proven carcinoma breast cases and in 100 age matched controls.

\section{RESULTS}

Predominance in arch pattern, a pattern intensity of less than 10 in both hands, TFRC less than 70, AFRC less than 80, a-b ridge count of less than 30 in the left hand and an atd angle of less than 45 were significantly associated with carcinoma breast.

\section{CONCLUSION}

The present study showed a significant association between the various dermatoglyphic patterns and carcinoma breast. So it may be used as a screening tool in early detection of carcinoma breast in high risk population.

\section{KEYWORDS}

Dermatoglyphics, Digital Patterns, TFRC, AFRC, a-b Ridge Count, atd Angle, Carcinoma, Screening.

HOW TO CITE THIS ARTICLE: Krishnan S, Natesan D. Dermatoglyphics in carcinoma breast. J. Evolution Med. Dent. Sci. 2016;5(89): 6630-6633, DOI: $10.14260 /$ jemds/2016/1500

\section{BACKGROUND}

Dermatoglyphics is the scientific study of the intricate details of the ridge structure of the fingers, palms, sole and toes. They are unique to the individual, but are highly variable for their number, type, shape and position. These patterns develop at birth and remain constant throughout life. Dermatoglyphics is recognised as a scientific method for medicolegal, anthropologic and genetic studies. ${ }^{1}$ It can also be used as a screening tool.

Breast cancer is one of the most common cancers affecting the female and its genetic and hereditary basis is well established. The available screening tools, mammography and genetic examination are expensive and require skilled medical persons and a well-equipped tertiary care hospital.

In humans, the milk ridge and the mammary bud along this milk line develop during the $6^{\text {th }}$ week of intrauterine life. During this same period, the dermal ridges along the volar pads also develop. The genetic message in the genome deciphered during this period is reflected by dermatoglyphics.

Available literature search did not show any studies pertaining to dermatoglyphics and carcinoma breast in Kerala. This study was undertaken as a pilot venture to establish the

Financial or Other, Competing Interest: None.

Submission 19-10-2016, Peer Review 31-10-2016,

Acceptance 02-11-2016, Published 07-11-2016.

Corresponding Author:

Dr. Savithri Krishnan,

House No. 5, Vishnu Nagar,

Pappanamcode P.O., Trivandrum-695018.

E-mail:drsachi@gmail.com

DOI: $10.14260 /$ jemds/2016/1500 dermatoglyphic parameters in carcinoma breast in Kerala.

The objective of this study was to find out the relationship between the dermatoglyphic features and carcinoma breast, and also to explore the possibility of this method as a cheap and effective screening tool in a susceptible population.

\section{MATERIALS AND METHODS}

\section{Sample Size}

200 subjects were included in the study. 100 patients in the age group 20-75, with histopathologically proven carcinoma breast were randomly selected from the Departments of Surgery and Radiotherapy of the Govt. T D Medical College, Alappuzha, Kerala and compared with 100 age matched controls who did not have a family history of carcinoma breast, or any cancers.

Impressions of all the 10 fingertips and right and left palms were taken by the Roller and Ink method of Purvis-Smith ${ }^{2}$. After taking informed consent from each subject, impressions were taken on an executive bond paper using printer's ink, roller and glass slab. A small amount of ink was applied on the glass slab and spread into a thin film with the roller. After cleaning and drying the hand, it was pressed firmly against the glass slab. Palmar impressions included the area from the distal crease on the wrist to the metacarpophalangeal crease and both ulnar and radial side of the ridge areas. For better impressions, hollow of the palm was rolled over the paper covered cylinder. In taking the impressions of the fingers, the pulp of the finger was kept at right angles to the surface of the paper and then rolled until the pulp faced the opposite direction.

The name and age of both cases and controls were written on top right end of the paper. Using a magnifying lens and 
needle, fingertip patterns were counted and dermatoglyphic landmarks marked.

Fingertip patterns are arches, loops whorls and accidentals and dermatoglyphic landmarks include triradius and core. ${ }^{3}$

\section{Qualitative Analysis}

Include fingertip patterns and pattern intensity.

Fingertip Patterns- The type of patterns in the fingertip was counted in the order from the little finger to thumb in the left hand and from the thumb to little finger in the right hand.

Pattern Intensity- Triradius refers to the confluence of 3 ridge systems and pattern intensity denotes the number of triradii present.

\section{Quantitative Analysis}

Core is the approximate center of the pattern and in ridge counting the distal tip of the straight line forming the core is used. Ridge counting is done along a straight line connecting the triradial point to the core. Ridges containing the point of core and triradial point are both excluded. Ridges are counted from the little finger to thumb in the left hand and from the thumb to little finger in the right hand.

Method of ridge counting in various patterns are given in Figure 1.

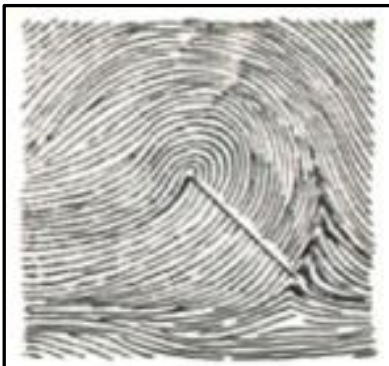

A

C

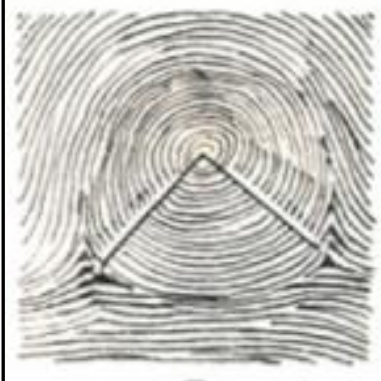

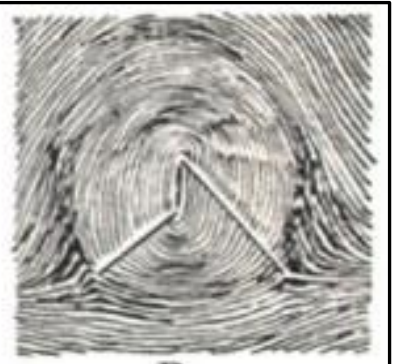

B

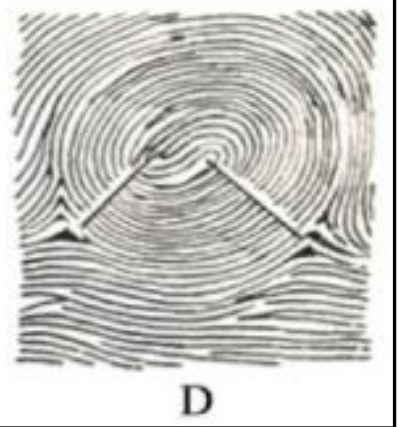

D
Figure 1. Ridge Counting in Various Fingertip Patterns A-loops B, C \& D-Whorls

Total Finger Ridge Count/TFRC-TFRC is the sum of the ridge counts in all the ten fingers.

Absolute Finger Ridge Count- AFRC is the sum of ridge counts from the separate triradii of all the fingers.

a-b Ridge Count- is the ridge count between 2 adjacent digital triradius a \& b. Counting is done along the straight line connecting them (Fig 2).

Atd Angle- is the angle subtended by lines drawn from digital triradius ' $a$ ' to axial triradius' $t$ ' and digital triradius' $d$ ' (Figure 2). This is measured using a protractor. This determines the axial triradial point.

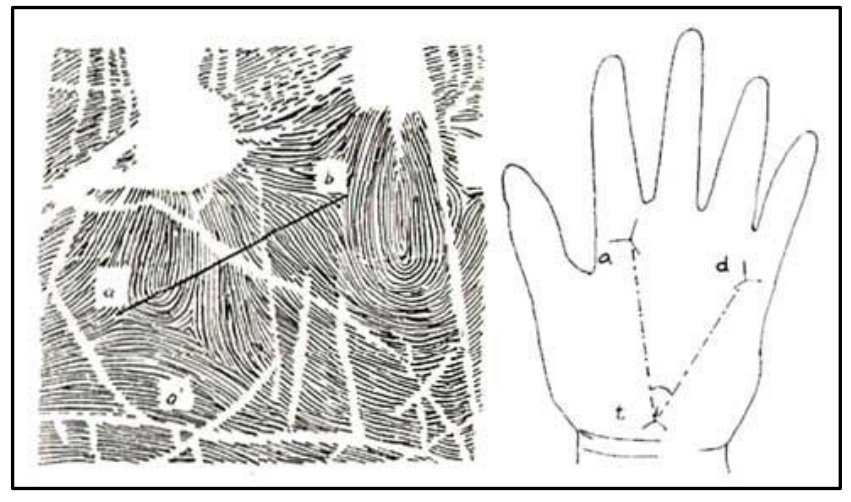

Figure 2. Method of Measuring a-b Ridge Count (left) and atd Angle (right)

All the findings were entered in the master chart which also had the serial number and age of both cases and controls. The significance of these values was determined using the chisquare test and $\mathrm{p}$ value determined.

\section{RESULTS}

\section{Fingertip Patterns}

$38 \%$ of cases and $24 \%$ of controls had a predominance of arch patterns. An equal proportion of both cases and controls showed loops and so was the case of whorls. $98 \%$ of cases and $94 \%$ of controls had loops. $81 \%$ of cases and $80 \%$ of controls had loops (Table I).

\begin{tabular}{|c|c|c|c|}
\hline Pattern Type & Cases & Controls & P value \\
\hline Arches & 38 & 24 & 0.032 \\
\hline Loops & 98 & 94 & $>0.05$ \\
\hline Whorls & 81 & 80 & $>0.05$ \\
\hline Accidentals & 02 & 03 & $>0.05$ \\
\hline \multicolumn{3}{|c|}{ Table 1. Frequency of Fingertip } \\
Patterns in Cases and Controls
\end{tabular}

There was a significant association between the presence of arches and cases with a $\mathrm{p}$ value of 0.032 . No significant association between the presence of whorls or loops and cases were seen in the present study.

\section{Pattern Intensity}

Less than 10 was observed in $47 \%$ of cases and $27 \%$ of controls in the right hand. In the left hand, a pattern intensity of less than 10 was found in $43 \%$ of cases and $24 \%$ of controls (Table II).

\begin{tabular}{|c|c|c|c|c|}
\hline \multirow{2}{*}{$\begin{array}{c}\text { Pattern } \\
\text { Intensity }\end{array}$} & \multicolumn{2}{|c|}{ Right Hand } & \multicolumn{2}{c|}{ Left hand } \\
\cline { 2 - 5 } & Cases & Controls & Cases & Controls \\
\hline Less than 10 & 47 & 27 & 43 & 24 \\
\hline More than 10 & 53 & 73 & 57 & 76 \\
\hline \multicolumn{3}{|c|}{ Table II. Frequency of Pattern } \\
Intensity and Carcinoma Breast \\
\hline
\end{tabular}

There was a significant association with pattern intensity of less than 10 and cases in right hand ( $p$ value- 0.005 ) as well as in the left hand ( $p$ value-0.007). 


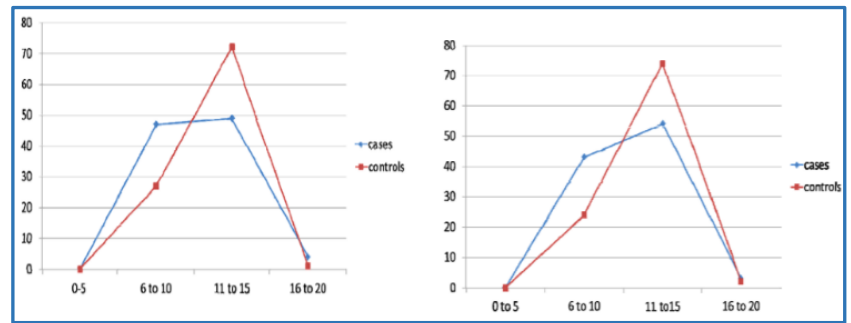

Figure 3. Line Diagram showing the Frequency of Pattern Intensity in Right and Left Hands in Cases and Controls

The number of cases and controls with a pattern intensity in a range between 6 to $10(<10)$ and between 11 to $15(>10)$ in the right and left hands is depicted in the line diagram (Figure 3). From the above figure, it is clear that pattern intensity of less than 10 is observed more in cases than controls in both hands.

\section{Quantitative Analysis}

\section{Total Finger Ridge Count}

Among the study population, TFRC less than 70 was found in 71 cases and 15 controls whereas TFRC of more than 70 was seen in 29 cases and 85 controls (Table III).

A significant association between TFRC less than 70 and carcinoma breast (p-0.017) was observed in this study.

\section{Absolute Finger Ridge Count}

AFRC of less than 80 was seen in 32 cases and 18 controls whereas more than 80 was seen in 68 cases and 82 controls (Table III).

A significant association between AFRC less than 80 and carcinoma breast was present $(\mathrm{p}=0.033)$.

\begin{tabular}{|c|c|c|c|}
\hline Finger Ridge Count & Cases & Controls & P value \\
\hline TFRC & & & \\
\cline { 2 - 4 } $\begin{array}{c}\text { Less than } 70 \\
\text { More than } 70\end{array}$ & 71 & 15 & 0.017 \\
\cline { 2 - 4 } AFRC & 29 & 85 & $>0.05$ \\
\hline $\begin{array}{c}\text { Less than } 80 \\
\text { More than 80 }\end{array}$ & 32 & 18 & 0.033 \\
\cline { 2 - 4 } Table III. Frequency of Finger Ridge \\
Count in Cases and Controls \\
\hline \multicolumn{3}{|c}{} \\
\hline
\end{tabular}

AFRC was categorised into 4 groups depending on the number of ridges and the results plotted in a histogram (Figure 4).

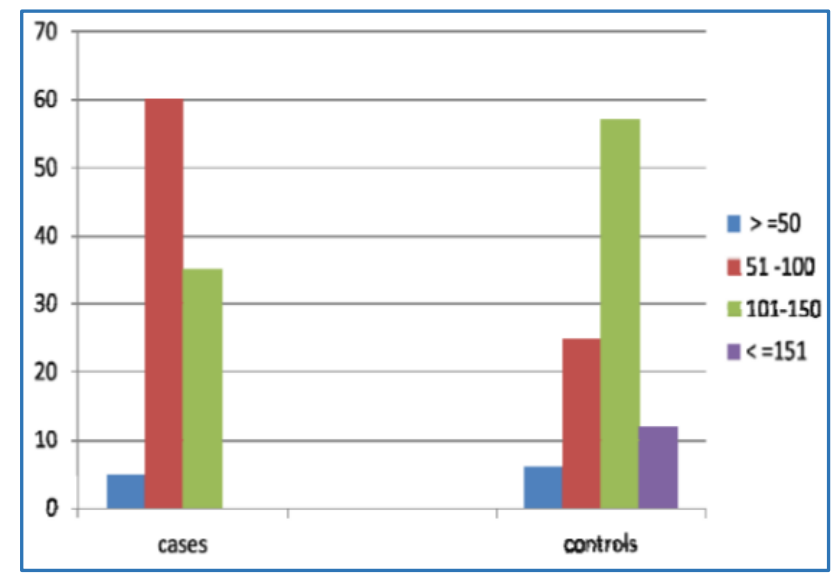

Figure 4. Histogram showing AFRC in Cases and Controls a-b Ridge Count- A-b ridge count less than 30 was found in 84 cases and 70 controls in the left hand. In the right hand, a-b ridge count of less than 30 was seen in 79 cases and 80 controls (Table IV).

\begin{tabular}{|c|c|c|c|c|}
\hline \multirow{2}{*}{$\begin{array}{l}\text { a-b Ridge } \\
\text { Count }\end{array}$} & \multicolumn{2}{|c|}{ Right Hand } & \multicolumn{2}{|c|}{ Left Hand } \\
\hline & Cases & Controls & Cases & Controls \\
\hline Less than 30 & 79 & 80 & 84 & 70 \\
\hline More than 30 & 21 & 20 & 16 & 30 \\
\hline & \multicolumn{2}{|c|}{$P$ value $>0.05$} & \multicolumn{2}{|c|}{$\mathrm{P}$ value 0.028} \\
\hline \multicolumn{5}{|c|}{$\begin{array}{c}\text { Table IV. Frequency of a-b Ridge } \\
\text { Count in Cases and Controls }\end{array}$} \\
\hline
\end{tabular}

A significant association between $\mathrm{a}-\mathrm{b}$ ridge and carcinoma breast with p value of 0.028 was seen on the left hand.

Atd Angle- Mean atd angle was calculated. A value of less than 45 was observed in 50 cases and 24 controls. In 50 cases and 76 controls, atd angle of more than 46 was present.

A significant association of atd angle less than 45 and carcinoma breast was seen with p value 0.017 (Table V).

\begin{tabular}{|c|c|c|}
\hline Atd Angle & Less than $\mathbf{4 5}^{\circ}$ & More than $\mathbf{4 5}^{\mathbf{0}}$ \\
\hline Cases & 50 & 50 \\
\hline Controls & 24 & 76 \\
\hline & P value 0.017 & P value $>0.05$ \\
\hline \multicolumn{3}{|c|}{ Table V. Frequency of atd } \\
& Angle in Cases and Controls \\
\hline
\end{tabular}

\section{DISCUSSION}

\section{Fingertip Patterns}

The present study showed an increased arch pattern in the fingertips in both hands in carcinoma breast cases and was statistically significant in conformity with Oladipo ${ }^{4}$ Shivaji ${ }^{5}$ Kavita ${ }^{6}$ and Aprajitha. ${ }^{7}$ There was no significant association between the presence of whorl patterns and carcinoma in this study as against Devgan ${ }^{8}$ and Lavanya. ${ }^{9}$

\section{Pattern Intensity}

Pattern intensity refers to the complexity of ridge configurations. Pattern intensity and carcinoma breast showed a significant relation to each with a value of less than 10 in right and left hands. ${ }^{9}$ An increased value was reported by Devgan. ${ }^{8}$ which is in contrast with the present study.

\section{TFRC}

The association of ridge count and cancer was reported as early as in $1972 .{ }^{1}$ A significant association between TFRC and carcinoma breast was observed in this study. Similar findings were reported by Oladipo, ${ }^{4}$ Shivaji, ${ }^{5}$ Aprajitha ${ }^{7}$ and Lavanya. ${ }^{9}$

\section{AFRC}

A significant association between a decrease in AFRC and carcinoma breast was seen in this study. Shivaji, ${ }^{5}$ Aprajitha $^{7}$ also reported a significant decrease in both TFRC and AFRC. Sridevi ${ }^{10}$ has reported an increase in both TFRC and AFRC in carcinoma breast cases, but the present study showed a decrease in both.

\section{a-b Ridge Count}

A significant association of $a-b$ ridge count with carcinoma breast in the present study was also noted by Shivaji, ${ }^{5}$ Devgan, 8 
Natekar ${ }^{11}$ and Yunyu Zhou. ${ }^{12}$ An increased a-b ridge count was reported by Sridevi, ${ }^{11}$ and Fuller ${ }^{1}$ in his studies has observed that $\mathrm{a}-\mathrm{b}$ ridge count do not change in cancers.

\section{atd Angle}

A significant lower angle was noted here and was in uniformity with the findings reported by Oladipo ${ }^{4}$, Lavanya ${ }^{9}$, Natekar ${ }^{10}$ and Sridevi. 11

\section{Screening Tool}

The present study on the dermatoglyphics and carcinoma breast suggests that this method can be used as an effective screening tool. The importance of dermatoglyphics as a valuable aid in screening campaigns was reported as early in 1983 by Harvey. ${ }^{13}$ Further studies conducted at national and international level emphasised the use of dermatoglyphics as an anatomical, effective, noninvasive, cheap and easy screening tool in high risk population.14,15,16 The dermatoglyphics in breast cancers can also be used as a predictor tool17 and can also serve as a basis for future research.?

\section{CONCLUSION}

An increase in the arch pattern, low pattern intensity in hands, a decreased total and absolute finger ridge count, a decreased $a-b$ ridge count in the left hand and a decreased ATD angle were significantly associated with carcinoma breast. Similar studies conducted at different centres in the country will help to standardise the dermatoglyphic markers. When done, this could be effectively used as a screening tool in hospitals and medical camps to assess the risk of carcinoma breast in a susceptible population.

\section{REFERENCES}

1. Fuller IC. Inherited predisposition to cancer? A dermatoglyphics study. British Journal of cancer 1973: 28(2):186-9.

2. Purvis-Smith SG. Finger and palm printing techniques for the clinician. Med J Austr 1969;2(4):189-91.

3. Schaumann B, Alter M. Dermatoglyphics in medical disorders. New York: Springer-Verlag 1976:85-98.

4. Oladipo GS, MK Sapira. Study of digital and palmar dermatoglyphic patterns of Nigerian women with malignant mammary neoplasm. Journal of Applied Biosciences 2009;15:829-34.
5. Sukre SB, Laeeque M, Mahajan A, et al. Dermatoglyphics in identification of women either with or at risk of Breast Cancer. International Journal of Basic Medical Sciences 2012;3(5):160-4.

6. Pahuja K, Geeta, Singh J, et al. Analysis of the qualitative and quantitative dermatoglyphic traits in breast cancer patients association with ABO blood group. Asian journal of Pharmaceutical \& Health Sciences 2013;3(2):705-9.

7. Raizada A, Johri V, Ramnath T. A cross sectional study on the palmar dermatoglyphics in relation to carcinoma breast patients. Journal of Clinical Diagnosis Res 2013;7(4):609-12.

8. Devgan, Arushi, Chintamani. Qualitative and Quantitative dermatoglyphic traits in Patients with breast cancer: A prospective clinical study. New Indian Journal of Surgery 2011;2(4):230-4.

9. Lavanya JP, Saraswathy P, Vijayakumar J, et al. Analysis of Dermatoglyphic traits in Patients of breast cancer. Journal of Pharmacology and Biomedical Sciences 2012;23(24):15 .

10. Sridevi NS, Silvia CRWD, Kulkarni R, et al. Palmar dermatoglyphics in carcinoma breast of Indian women. Rom J of Morphology \& Embryology 2010;51(3):547-50.

11. Natekar PE, Desouza FM. Fluctuating asymmetry in dermatoglyphics of carcinoma breast. Anthropologist 2006;12(2):76-81.

12. Zhou Y, Zeng Y, Lizen, et al. Application \& development of palm print research. Technology \& Health Care 2002;10(5):383-90.

13. Harvey RG, Suter D. Evidence for a major gene effect in the distribution of ridge counts. Annals on Human Biology 1983;10(6):565-77.

14. Seltzer MH, Plato CC, Fox KM. Dermatoglyphics in the identification of women either with or at risk of breast cancer. Am J of Medical Genetics 1990;37(4):482-8.

15. Abbasim S, Einollahi N, Dashti N, et al. Study of dermatoglyphic patterns of hands in women with breast cancer. Pak Journal of Medical Sciences 2006;22(1): 18-22.

16. Abhilasha S, Harisudha R, Janaki CS. Dermatoglyphics: a predictor tool to analyse the occurrence of breast cancer. IJMRHS 2014;3(1):28-31.

17. Kalpana S, Rajesh A, Amritha P. A study of dermatoglyphics patterns ('atd', 'tad','tda') of hands in patients of breast cancer in Jhalawar region. Indian Journal of Anatomy 2015;4(2):61-4. 